\title{
Organizacja i funkcjonowanie związków międzygminnych w Polsce
}

\section{Magdalena ZioŁo ${ }^{1}$, Bartosz Oliwa ${ }^{2}$}

1 dr hab. prof. US, Uniwersytet Szczeciński, Wydział Zarządzania i Ekonomiki Usług e-mail: magdalena.ziolo@wzieu.pl

2 mgr, Uniwersytet Szczeciński, Wydział Zarządzania i Ekonomiki Usług e-mail: oliwa.bartosz@gmail.com.

SŁoWA KLUCZOWE zWiązki międzygminne, samorząd terytorialny, gospodarka finansowa, finanse publiczne

ABSTRAKT $\quad \mathrm{Cel}$ - podjęto próbę uporządkowania i usystematyzowania stanu wiedzy z zakresu funkcjonowania związków międzygminnych w Polsce, ich otoczenia prawnego i organizacji oraz wskazano na finansowe aspekty i uwarunkowania działalności związków. W części empirycznej opracowania zaprezentowano dotychczasowe doświadczenia w funkcjonowaniu związków międzygminnych i realizacji przez nie zadań publicznych ze szczególnym uwzględnieniem ich dysfunkcjonalności zdiagnozowanej w wyniku działalności kontrolnej NIK.

Metodyka badania - wykorzystano krytyczną analizę piśmiennictwa, ze szczególnym uwzględnieniem analizy aktów prawnych i raportów pokontrolnych NIK, zastosowano metody indukcji i dedukcji oraz metodę obserwacyjną.

Wynik - przegląd dotychczasowych doświadczeń w funkcjonowaniu związków międzygminnych w aspekcie teoretycznym i praktycznym wskazuje, że o ile ramy formalnoprawne dla funkcjonowania tych podmiotów są wystarczające, o tyle respektowanie wymogów prawnych w praktyce nie zawsze przebiega w sposób prawidłowy, co wynika zazwyczaj z braku doświadczenia decydentów lub ich niewiedzy. Skala nieprawidłowości jest niewielka, jakkolwiek częstotliwość i liczebność ich występowania znaczna. Należy oczekiwać, że wobec rosnącej liczby zadań przypisanych gminom do realizacji przy niezmienionym stanie ich finansów popularność związków międzygminnych, jako formy realizacji zadań publicznych będzie rosła.

Wartość - w artykule w kompleksowo zaprezentowano rzadko podejmowaną w literaturze przedmiotu problematykę zogniskowaną na związkach międzygminnych oraz aspektach organizacyjnych i finansowych ich funkcjonowania. Na uwagę zasługuje w szczególności diagnostyka dysfunkcji w sferze funkcjonowania związków międzygminnych, słabo opisana w literaturze przedmiotu a zaprezentowana w artykule.

\section{Organization and functioning of intermunicipal unions in Poland}

KEYWORDS

ABSTRACT union of communes, local government, financial management, public finances

Purpose - in an article authors attempted to organize and systematize the knowledge of the functioning of the union of communes in Poland, their legal environment, organization and the financial aspects and determinants of their activities. In the empirical part of the paper authors presented the experience in functioning of union of communes and their implementation of public 
tasks with particular regard to their dysfunctionality diagnosed as a result of the Supreme Chamber of Control audit activity.

Methodology - the article uses critical analysis of literature with particular emphasis on the analysis of legal acts and audit reports of the Supreme Chamber of Control, methods of induction and deduction, and observational methods.

Findings - reviewing previous experience in the functioning of union of communes relations in the theoretical and practical aspects indicates that while the formal legal framework for the functioning of these entities is sufficient, the legal requirements in practice is not always normal, which is usually result of the lack of experience of decision makers or their knowledge. The range of irregularity is small, although the frequency and abundance of their occurrence are considerable. It is expected that in the face of the increasing number of tasks assigned to municipalities to carry out their unchanged state of finances, the popularity of unions of communes as a form of implementation of public tasks will increase.

Value - the research paper in a complex way presents the rarely depicted in the reference books issues of the union of communes and the organizational and financial aspects of its operations. Particularly noteworthy is the diagnostics of dysfunction in the area of the union of communes' functioning, poorly described in the literature and presented in the article.

\section{Formalnoprawne uwarunkowania funkcjonowania związków międzygminnych}

Polskie uwarunkowania legislacyjne dopuszczają możliwość tworzenia zróżnicowanych form organizacyjno-prawnych w celu współdziałania jednostek samorządu terytorialnego (JST) polegającego na współrealizacji przez te jednostki zadań publicznych. Zazwyczaj sytuacja taka dotyczy wykonywania zadań, które z uwagi na różne uwarunkowania wewnętrzne i zewnętrzne są trudne do podjęcia lub wręcz niemożliwe do samodzielnego wykonania przez daną jednostkę samorządową. Do popularnych form współpracy jednostek terytorialnych zalicza się związki $\mathrm{JST}^{1}$, które w literaturze przedmiotu definiowane są jako „odrębne od ich uczestników podmioty mające osobowość prawną i podmiotowość publicznoprawną” (Stahl, Jaworska-Dębska, 2010, s. 306). Wśród najczęstszych przesłanek tworzenia takich związków można wymienić te o charakterze: finansowym, organizacyjnym, infrastrukturalnym, przestrzennym oraz środowiskowym (Ofiarska, 2012, s. 205).

W praktyce jednak najczęściej wykorzystywaną formułą współpracy są związki międzygminne, określane także mianem związków komunalnych lub międzykomunalnych.

Podstawy dla funkcjonowania związków gmin określa art. 64 (i dalsze) Ustawy z 8 marca 1990 roku o samorządzie gminnym (Dz.U. 2016, poz. 446). Dopuszcza się dualny² (przymusowy lub dobrowolny) charakter powoływania związków międzygminnych, tj. mogą być one tworzone dobrowolnie przez ich uczestników lub wynikać z obowiązku ustawowego - art. 64 ust. 4 (Ustawa z 8.03.1990 r. o samorządzie gminnym, Dz.U. 2016, poz. 446).

\footnotetext{
${ }^{1}$ Przepisy pozwalają na tworzenie związków przez takie JST jak gminy, gminy i miasta na prawach powiatu, powiaty i miasta na prawach powiatu.

${ }^{2}$ Powiaty tworzą swoje związki wyłącznie w trybie autonomicznych decyzji, tj. dobrowolnie.
} 
Tworzenie związków międzygminnych (oraz JST), przystępowanie do związków już istniejących, rozwiązywanie ich lub występowanie z nich wymaga od organów decyzyjnych stosownych uchwał w przedmiotowych sprawach. Organy stanowiące JST mają także kompetencje do określenia zakresu zadań publicznych przekazywanych związkowi przez poszczególne JST tworzące dany związek (Ofiarska, 2012, s. 205).

Z punktu widzenia prawidłowego funkcjonowania związku międzygminnego wymaganym dokumentem jest statut, który jest niezbędny do utworzenia związku i nabycia przez niego osobowości prawnej. Określa on zadania związku, na podstawie których realizowana aktywność rodzi konsekwencje formalnoprawne związane m.in. z podejmowaniem decyzji, właściwością organów i odpowiedzialnością (Kiełbus, 2012, s. 56). Zadania związku i tryb zatwierdzenia statutu określa ustawa - art. 64 ust. 4 (Ustawa z 8.03.1990 r. o samorządzie gminnym, Dz.U. 2016, poz. 446).

Powołanie związku międzygminnego wymaga podjęcia stosownych uchwał przez wszystkie zainteresowane współdziałaniem gminy - art. 64 ust. 2 (Ustawa z 8.03.1990 r. o samorządzie gminnym, Dz.U. 2016, poz. 446).

Ustawodawca nie precyzuje minimalnej i maksymalnej liczby gmin, jakie mogą tworzyć związek. Logicznie uzasadniony jest jednak warunek, że związek powinien składać się z co najmniej dwóch gmin, a z punktu widzenia organizacyjno-zarządczego liczba gmin tworząca związek powinna być adekwatna do charakteru i zakresu powierzonych związkowi zadań.

W celu powołania związku ustawodawca wymaga określenia praw i obowiązków gmin w nim uczestniczących, wynikających z wykonywania wspólnych zadań. Powierzone zadania przechodzą na związek z dniem ogłoszenia jego statutu w wojewódzkim dzienniku urzędowym - art. 64 ust. 3 (Ustawa z 8.03.1990 r. o samorządzie gminnym, Dz.U. 2016, poz. 446).

Każda z gmin w jednakowym zakresie przenosi swoje zadania na nowo powstały związek międzygminny (Kiełbus, 2012, s. 56), tak więc związek ten ma tyle praw i obowiązków, ile miały uprzednio gminy (członkowie związku), przekazujące mu zadania (Kiełbus, 2012, s. 56).

Warunkiem bezwzględnie obowiązującym, i tym samym dopuszczającym tworzenie oraz działanie związku, jest jednoznacznie określony przedmiot jego aktywności, który musi koncentrować się na realizacji zadań publicznych ${ }^{3}$. Z uwagi na brak prawnej definicji pojęcia ,zadania publicznego", w sposób domniemany tego rodzaju zadania określić można jako zadania użyteczności publicznej wykonywane przez gminy w sposób nieprzerwany, na podstawie powierzonej im misji publicznej, służące zaspokajaniu potrzeb społeczności lokalnej zamieszkującej na podporządkowanym gminie/gminom obszarze.

M. Krawczyk (2011, s. 169) wskazuje, że w kompetencji związków międzygminnych znajdują się w tym ujęciu, zarówno zadania własne, jak i zadania zlecone. Autor zastrzega jednak, że związki międzygminne mogą być tworzone dla realizacji zadań zleconych w sytuacjach, gdy wyłączenie takiej możliwości nie wynika z porozumienia zawartego pomiędzy organem administracji rządowej i gminą na podstawie art. 8 ust. 2 ustawy o samorządzie gminnym (Dz.U. 2016, poz. 446). Przekazanie zadań zleconych związkowi międzygminnemu może odbyć się także w drodze porozumienia pomiędzy organem administracji rządowej, a danym związkiem gmin.

\footnotetext{
${ }^{3} \mathrm{~W}$ przypadku związków powiatów może to być także wydawanie decyzji w sferze administracji publicznej.
} 
Podjęcie uchwały o utworzeniu związku międzygminnego powinno zostać poprzedzone powiadomieniem właściwego wojewody, o czym stanowi art. 66 ustawy o samorządzie gminnym (Dz.U. 2016, poz. 446), jednak nie precyzuje, który organ ma wypełnić ten obowiązek informacyjny. Zakłada się więc, że może tego dokonać zarówno organ decyzyjny, jak i wykonawczy gminy.

Warunkiem bezwzględnym, który musi spełnić związek komunalny w celu uzyskania osobowości prawnej jest zarejestrowanie związku w rejestrze związków prowadzonym przez ministra właściwego do spraw administracji publicznej - art. 68 ust. 1 (Ustawa z 8.03.1990 r. o samorządzie gminnym, Dz.U. 2016, poz. 446). Po dokonaniu wpisu do rejestru związków, związek nabywa osobowość prawną, a działające w jego imieniu organy mogą skutecznie realizować przypisane im zadania.

Kompetencje decyzyjne i kontrolne ustawodawca powierzył zgromadzeniu związku art. 69 ust. 1 (Ustawa z 8.03.1990 r. o samorządzie gminnym, Dz.U. 2016, poz. 446), natomiast organem wykonawczym związku jest zarząd.

Podstawę prawną dla funkcjonowania zgromadzenia, a także w zakresie zadań zleconych związkowi, tworzą przepisy znajdujące zastosowanie dla organu jakim jest rada gminy - art. 69 ust. 2 (Ustawa z 8.03.1990 r. o samorządzie gminnym, Dz.U. 2016, poz. 446). Zgromadzenie tworzą wójtowie gmin - członkowie związku, jednak na wniosek wójta rada gminy może wyznaczyć także zastępcę wójta lub jednego z radnych - art. 70 ust. 2 (Ustawa z 8.03.1990 r. o samorządzie gminnym, Dz.U. 2016, poz. 446).

Zazwyczaj każdej gminie przysługuje jeden głos w zgromadzeniu, z zastrzeżeniem, że określonym gminom może być przyznany na podstawie statutu więcej niż jeden głos. Wówczas dodatkowych przedstawicieli z takiej gminy wyznacza jej rada.

Do wyłącznej właściwości zgromadzenia związku należy m.in. podejmowanie uchwał w sprawach majątkowych związku (Ofiarska, 2012, s. 209), przyjmowanie zadań rządowych i samorządowych, przystępowanie do międzynarodowych zrzeszeń społeczności lokalnych i regionalnych (Ofiarska, 2012, s. 205), współpraca ze społecznościami innych państw, a także zarządzanie majątkiem i zobowiązaniami związku (Ofiarska, 2012, s. 205).

Zgromadzenie podejmuje uchwały, które są przyjmowane bezwzględną większością głosów statutowej liczby członków zgromadzenia - art. 71 (Ustawa z 8.03.1990 r. o samorządzie gminnym, Dz.U. 2016, poz. 446). Członkowi zgromadzenia przysługuje prawo wniesienia sprzeciwu wobec przyjmowanych przez zgromadzenie uchwał w terminie 7 dni liczonych od momentu podjęcia uchwały, w formie pisemnej (art. 72 ust. 1, Ustawa z 8.03.1990 r. o samorządzie gminnym, Dz.U. 2016, poz. 446). Wniesienie sprzeciwu przez członka zgromadzenia wobec podjętej uchwały skutkuje zawieszeniem jej wykonania i skierowaniem jej do ponownego rozpoznania w przedmiocie kwestii spornych. Uchwała podjęta po uwzględnieniu sprzeciwu nie daje członkom zgromadzenia możliwości ponownego kwestionowania jej treści i tym samym ponownego wnoszenia sprzeciwu wobec zmodyfikowanych zapisów uchwały4.

Uprawnieniem przysługującym zgromadzeniu związku jest powołanie i odwołanie organu wykonawczego - zarządu, który jest powoływany z członków zgromadzenia. Dopuszcza się

\footnotetext{
${ }^{4}$ Przepisów dotyczących sprzeciwu wobec uchwał zgromadzenia nie stosuje się w przypadku związków międzygminnych powoływanych obligatoryjnie na podstawie właściwych ustaw.
} 
wybór członków zarządu spoza członków zgromadzenia w sytuacji, gdy stanowi o tym statut. Liczba członków pochodzących spoza zgromadzenia nie może przekraczać 1/3 składu zarządu związku (art. 73 ust. 3, Ustawa z 8.03.1990 r. o samorządzie gminnym, Dz.U. 2016, poz. 446).

Kompetencje zarządu podlegają regulacjom prawnym odnoszącym się do organów wykonawczych gmin oraz powinny zostać określone w statucie związku. Do wyłącznych kompetencji zarządu związku należy wykonywanie uchwał zgromadzenia związku, gospodarowanie mieniem związku, kierowanie sprawami bieżącymi związku, reprezentacja związku (Ofiarska, 2012, s. 209).

Przedsięwzięcia realizowane przez związki międzygminne zgodnie z obowiązującym prawem mogą być realizowane w kilku różnych formach. W zależności od tego jaką decyzję w tym zakresie podejmie zgromadzenie związku, przedsięwzięcie może być wykonywane przez ten podmiot w formie: porozumienia, samorządowego zakładu budżetowego lub spółki prawa handlowego. Wybór formy realizacji przedsięwzięcia determinuje więc źródła jego finansowania oraz podstawę prawną dla jego wykonania. Ustawa z dnia 20 grudnia 1996 r. o gospodarce komunalnej (Dz.U. 2016 poz. 573), której podlegają związki międzygminne w art. 2 wskazuje, że gospodarka komunalna może być prowadzona w formie samorządowego zakładu budżetowego lub spółek prawa handlowego. Regulacje właściwe dla samorządowych zakładów budżetowych zawiera także Ustawa z 27 sierpnia 2009 roku o finansach publicznych (Dz.U. 2009, nr 157, poz. 1240, z późn. zm.), która określa zamknięty katalog zadań zastrzeżony dla aktywności samorządowych zakładów budżetowych ${ }^{5}$, stąd wybór tej formy realizacji przedsięwzięć przez związki międzygminne nie pozostaje dowolny i determinowany jest charakterem przedsięwzięcia.

Podstawą gospodarki finansowej związku międzygminnego jest jego budżet, a gospodarka finansowa związku jest prowadzona zgodnie z przepisami dotyczącymi gospodarki finansowej gmin. Tym samym, zasady gospodarowania publicznym pieniądzem określone przez przepisy prawa finansowego wyznaczają zasady obowiązujące związki międzygminne w procesie gospodarowania ich finansami. W zakresie gospodarki finansowej związków międzygminnych zastosowanie znajdują takie same przepisy, jakim podlegają gminy, tj. ustawa o finansach publicznych (Dz.U. 2009, nr 157, poz. 1240, z późn. zm.), ustawa o rachunkowości (Dz.U. 2016, poz. 1047) oraz dwa rozporządzenia Ministra Finansów6

W literaturze przedmiotu gospodarka finansowa traktowana jest jako „,zespół czynności faktycznych i prawnych polegających na pozyskiwaniu środków pieniężnych i korzystaniu z nich zgodnie z celami i zadaniami danej jednostki i obowiązujących ją reguł postępowania ze środkami pieniężnymi” (Ofiarska, 2012, s. 46). Przedmiotem gospodarki finansowej jest więc proces gromadzenia i wydatkowania środków publicznych dokonujący się z zachowaniem określonych uprzednio zasad racjonalnego gospodarowania przez podmioty do tego uprawnione.

\footnotetext{
${ }^{5}$ Zadania samorządowych zakładów budżetowych określa art. 14 ustawy o finansach publicznych (Dz.U. 2009, nr 157, poz. 1240 z późn. zm.).

${ }^{6}$ Rozporządzenie Ministra Finansów z 5.07.2010 r. w sprawie szczególnych zasad rachunkowości oraz planów kont dla budżetu państwa, budżetów jednostek samorządu terytorialnego, jednostek budżetowych, samorządowych zakładów budżetowych, państwowych funduszy celowych oraz państwowych jednostek budżetowych mających siedzibę poza granicami Rzeczypospolitej Polski (Dz.U. 2010, nr 128, poz. 861 z późn. zm.) oraz rozporządzenie Ministra Finansów z 2.03.2010 r. w sprawie szczegółowej klasyfikacji dochodów, wydatków, przychodów i rozchodów oraz środków pochodzących ze źródeł zagranicznych (Dz.U. 2010, nr 38, poz. 207 z późn. zm.).
} 
W zakresie gromadzenia dochodów przez związki międzygminne należy zwrócić uwagę na ich źródła oraz czynniki determinujące ich strukturę. Dochody związku zależne są od przedmiotu jego działania oraz formy, realizacji przedsięwzięć, wybranej przez związek.

Budżet związku jest zasilany dwoma rodzajami dochodów, tj. dochodami bieżącymi oraz dochodami o charakterze majątkowym ${ }^{7}$. Źródłami finansowania zadań powierzonych związkom do realizacji mogą być udziały i składki wnoszone przez uczestników (gminy), dochody z prowadzonej działalności gospodarczej związku i majątku, środki z budżetu państwa, darowizny, spadki, zapisy, dotacje, kredyty, pożyczki, środki z programów pomocowych, w tym środki z budżetu Unii Europejskiej (Interpretacja Dyrektora Izby Skarbowej w Katowicach, 2009).

Istotny wpływ na rodzaj dochodów pozyskiwanych przez związek ma forma realizacji wykonywanych przez niego przedsięwzięć. Jeżeli związek jest stroną porozumienia, na podstawie którego przedsięwzięcie jest realizowane, wówczas otrzymuje on środki finansowe niezbędne do prawidłowego wykonania zadania $\mathrm{w}$ formie dotacji celowej, podlegającej regulacjom Ustawy z 13 listopada 2003 roku o dochodach jednostek samorządu terytorialnego (Dz.U. 2016, poz. 198). Szczegóły finansowania powinno ponadto określać porozumienie, którego stroną jest związek międzygminny.

Podobnie kształtuje się kwestia realizacji przedsięwzięć w formie samorządowego zakładu budżetowego, który na mocy przepisów Ustawy z 27 sierpnia 2009 roku o finansach publicznych (Dz.U. 2009, poz. 1240, nr 157 z późn. zm.) ma prawo do otrzymania dotacji na pierwsze wyposażenie w środki obrotowe w wysokości nieprzekraczającej 50\% kosztów działalności zakładu oraz dotacje przedmiotowe i dotacje celowe. W zakresie określonym przez odrębne ustawy dopuszcza się finansowanie samorządowych zakładów budżetowych z dotacji podmiotowych (art. 15 ust. 4 ustawy o finansach publicznych). Mając na uwadze finansowanie w formie dotacji należy pamiętać, że zakład budżetowy odpłatnie wykonuje zadania i pokrywa koszty swojej działalności z przychodów własnych, a jego gospodarka finansowa jest prowadzona na podstawie rocznego planu finansowego.

Ostatnią z form realizacji przedsięwzięć przez związek międzygminny jest spółka prawa handlowego, w przypadku której zastosowanie znajdują przepisy kodeksu spółek handlowych. W tej sytuacji głównym źródłem pozostają opłaty taryfowe uwzględniające koszty eksploatacji majątku (wnoszone w zamian za wykorzystanie majątku itp.) oraz dotacje (Ofiarska, 2012, s. 212).

Gdy źródła finansowania związku międzygminnego okażą się niewystarczające, dopuszczalne jest wykorzystanie przez związek finansowania zwrotnego (tytuły dłużne). Wysokość zobowiązań związków międzygminnych jest limitowana wskaźnikami zadłużenia określonymi dla JST w ustawie o finansach publicznych (Dz.U. 2009, poz. 1240, nr 157 z późn. zm). Do końca 2016 roku łączna kwota długu związku (JST) na koniec roku budżetowego nie może przekroczyć 60\% wykonanych dochodów ogółem tej jednostki w tym roku budżetowym (art. 170 Ustawy z 30.06.2005 r. o finansach publicznych, Dz.U. 2005, nr 249, poz. 2104 z późn. zm.). Łączna kwota przypadających w danym roku budżetowym spłat (realnych i potencjalnych) z tytułu zaciągniętych zobowiązań nie może natomiast przekroczyć 15\% planowanych na dany rok budżetowy dochodów danej jednostki (art. 169 ustawy o finansach publicznych, Dz.U. 2005, nr 249,

\footnotetext{
${ }^{7}$ Dochody bieżące są to dochody krótkoterminowe związane z działalnością operacyjną związku, mające charakter wpływów systematycznych. Dochody o charakterze majątkowym są to dochody osiągane w perspektywie długoterminowej, kreowane na bazie majątku związku, często w formie wpływów incydentalnych.
} 
poz. 2104 z późn. zm.). Gdy relacja państwowego długu publicznego do PKB przekroczy 55\%, to roczny limit spłat ulega zmniejszeniu i nie może przekroczyć 12\% planowanych dochodów.

Dla uchwał budżetowych obowiązujących od 2014 roku przyjęto odmienny sposób kalkulacji limitu zadłużenia bazujący na indywidualnym wskaźniku zadłużenia obliczanym zgodnie z formułą określoną w art. 243 ustawy o finansach publicznych (Dz.U. 2009, poz. 1240, nr 157 z późn. zm).

Związki międzygminne jako jednostki sektora finansów publicznych zobowiązane są do racjonalnego gospodarowania środkami pieniężnymi, co w szczególności wyraża się przez respektowanie art. 44 ust. 3 ustawy o finansach publicznych (Dz.U. 2009, poz. 1240, nr 157 z późn. zm.) stanowiącego, że wydatkowanie środków publicznych odbywa się w sposób celowy i oszczędny z zachowaniem zasad uzyskania najlepszych efektów z danych nakładów związanego z optymalnym doborem metod i środków służących osiągnięciu założonych celów.

Gospodarka finansowa związków międzygminnych prowadzona jest w sposób jawny, co wynika z generalnej zasady jawności finansów publicznych, a także zgodnie z przesłankami zawartymi w art. 44 ustawy o finansach publicznych (Dz.U. 2009, poz. 1240, nr 157 z późn. zm.), tj. powinna być realizowana z zachowaniem kryterium efektywności wydatkowania środków pieniężnych, a tym samym powinna zagwarantować stabilność finansów związku w krótkim i długim okresie.

Zapewnienie efektywności wydatków publicznych związku wymaga od jego decydentów wiedzy na temat narzędzi zarządzania finansami, w tym w szczególności planowania wieloletniego (obligatoryjny WPF${ }^{8}$ ) i budżetowania wydatków z uwzględnieniem ustawowych wymogów dotyczących polityki zadłużenia (limity długu).

Podstawowym narzędziem realizacyjnym gospodarki finansowej związków międzygminnych jest budżet, który traktowany jest jako plan finansowy, w ramach którego gromadzone są środki pieniężne służące finansowaniu określonych zadań (Kosek-Wojnar, Surówka, 2007, s. 64). Budżet związku jest zatem planem dochodów i wydatków, przychodów oraz rozchodów prognozowanych na okres roku budżetowego (rok kalendarzowy) przyjmowanym w formie uchwały budżetowej.

Procedura i tryb przyjmowania budżetu związku jest analogiczna jak w przypadku budżetu JST, wobec czego za obowiązujące dla związku w tym zakresie uznać należy właściwe przepisy Ustawy z 27 sierpnia 2009 roku o finansach publicznych. Zgromadzenie w drodze uchwały określa szczegółowy tryb prac nad budżetem związku (szczegółowość projektu budżetu, termin prac itp.). Projekt budżetu związku przygotowuje organ wykonawczy, któremu przysługuje wyłączna inicjatywa uchwałodawcza w tym zakresie. Zarząd związku jest prawnie zobligowany do przedłożenia projektu budżetu związku właściwej terytorialnie regionalnej izbie obrachunkowej w nieprzekraczalnym terminie do 15 listopada roku poprzedzającego rok budżetowy w celu zaopiniowania (art. 238 ust. 1 ustawy o finansach publicznych, Dz.U. 2009, nr 157, poz. 1240 z późn. zm.). Projekt budżetu związku wraz z częścią objaśniającą oraz załącznikami powinien

\footnotetext{
${ }^{8}$ Wieloletnia prognoza finansowa jest dokumentem planistycznym integrującym informacje prezentowane dotychczas w takich dokumentach jak: prognoza długu, wieloletni plan finansowy i wieloletni plan inwestycyjny. WPF pozwala na wskazanie wielkości środków finansowych, które mogą być wydatkowane na inwestycje oraz identyfikuje wielkość zapotrzebowania na finansowanie zwrotne. Szerzej: Budżet $i$ wieloletnia prognoza finansowa jednostek samorządu terytorialnego od projektu do sprawozdania (Salachna, 2010, s. 18-19; Krajewski, Mackiewicz, Krajewski, 2010, s. 51).
} 
zostać przedłożony członkom związku nie później, niż na 14 dni przed wniesieniem go pod obrady zgromadzenia. Sam budżet związku powinien zostać uchwalony przez zgromadzenie nie później niż do dnia 31 stycznia roku budżetowego (art. 240 ust. 1 ustawy o finansach publicznych, Dz.U. 2009, nr 157, poz. 1240 z późn. zm.). W przeciwnym wypadku, regionalna izba obrachunkowa do końca lutego roku budżetowego ustala budżet związku w zakresie zadań własnych oraz zadań zleconych (art. 240 ust. 3 ustawy o finansach publicznych, Dz.U. 2009, nr 157, poz. 1240 z późn. zm.). Do dnia ustalenia budżetu przez regionalną izbę obrachunkową podstawą gospodarki finansowej jest projekt uchwały. Za wykonanie budżetu JST oraz ogólny nadzór nad realizacją dochodów i wydatków oraz przychodów i rozchodów budżetu związku odpowiada jego zarząd.

Po zakończeniu roku budżetowego zarząd związku jest zobowiązany do wypełnienia określonych obowiązków sprawozdawczych względem zgromadzenia i regionalnej izby obrachunkowej. W szczególności do 31 marca roku następującego po roku budżetowym zarząd powinien przedłożyć sprawozdanie roczne z wykonania budżetu oraz informację o stanie mienia, której elementy wymienia art. 267 ust 1. pkt. 3 ustawy o finansach publicznych (Dz.U. 2009, nr 157, poz. $1240 \mathrm{z}$ późn. zm.).

Zgromadzenie związku po zapoznaniu się kolejno ze sprawozdaniem z wykonania budżetu związku, sprawozdaniem finansowym, opinią regionalnej izby obrachunkowej, informacją o stanie mienia oraz stanowiskiem komisji rewizyjnej w terminie do 30 czerwca roku następującego po roku budżetowym podejmuje uchwałę w sprawie absolutorium dla zarządu.

\section{Ocena działalności związków międzygminnych w świetle wniosków pokontrolnych NIK}

Związki międzygminne samodzielnie realizują swoją gospodarkę finansową i zarządzają powierzonym im mieniem. W ramach tych aktywności podmioty te pozyskują także środki unijne na współfinansowanie projektów realizowanych ze źródeł publicznych. Zakres działalności i rola związków międzygminnych systematycznie wzrasta a ich udział w gospodarowaniu środkami publicznymi sprawia, że stają się one ważnym podmiotem odpowiedzialnym za wydatkowanie publicznych zasobów. W celu zapewnienia prawidłowej realizacji gospodarki finansowej związków jednostki te podlegają nadzorowi i kontroli ze strony uprawnionych do tego organów (m.in. RIO, wojewoda).

W Polsce według stanu na 31 grudnia 2010 roku funkcjonowało 226 związków międzygminnych ${ }^{9}$, które realizowały zadania głównie z zakresu komunikacji miejskiej oraz gospodarki wodno-ściekowej. Mając na względzie rosnącą aktywność związków międzygminnych w zapewnianiu usług publicznych dla wspólnot lokalnych, warto zwrócić uwagę na ocenę dotychczasowego funkcjonowania tych podmiotów. Kontrola działalności sześciu związków z województw wielkopolskiego, łódzkiego, świętokrzyskiego, małopolskiego i śląskiego, przeprowadzona przez NIK w okresie od 17 września 2011 roku do 31 stycznia 2012 roku wykazała, że nie wszystkie podmioty były przygotowane do właściwej realizacji projektów, a w szczególności powiązanych

\footnotetext{
${ }^{9} 61 \mathrm{z}$ nich nie podjęło działalności. Por. Jak się ma gospodarka finansowa związów międzygminnych?, http://www. portalsamorzadowy.pl/prawo-i-finanse/jak-sie-ma-gospodarka-finansowa-zwiazkow-miedzygminnych,19676.html (10.11.2016).
} 
z nimi zadań inwestycyjnych (Informacja o wynikach kontroli..., 2012, s. 7). W opinii NIK determinantą tego stanu rzeczy jest nieprawidłowo funkcjonująca w związkach kontrola zarządcza, a wyeliminowanie nieprawidłowości wymaga zwiększenia skuteczności nadzoru nad ich działalnością ze strony uprawnionych do tego organów.

Przygotowanie finansowe związków do realizacji powierzonych im zadań inwestycyjnych oceniono pozytywnie. W szczególności zwrócono uwagę na zapewnienie trwałości finansowania rozpoczętych projektów przez zabezpieczenie (na mocy porozumień) partycypacji poszczególnych gmin - członków związku w finansowaniu podejmowanych wspólnie projektów. Pozytywnie oceniono także techniczne i organizacyjne działania związków wymagane dla prawidłowego ewidencjonowania operacji finansowych oraz kontroli rozliczeń (wyodrębnienie rachunków, ewidencji księgowej dla potrzeb projektu itp.).

Uwagi NIK dotyczyły przygotowania organizacyjnego związków i zagadnień wdrażania przepisów w zakresie kontroli zarządczej. Jak wskazują wnioski pokontrolne NIK, kontrola zarządcza powinna być realizowana w związkach międzygminnych na mocy przepisów Ustawy z 27 sierpnia 2009 roku o finansach publicznych, które w przeciwieństwie do audytu wewnętrznego (fakultatywny dla związków) mają charakter bezwzględnie obowiązujący (Informacja o wynikach kontroli..., 2012, s. 10). Tymczasem wśród badanych związków nie wszystkie z nich miały opracowany i wdrożony system kontroli zarządczej oraz określone procedury jej realizacji. Za niedopełnienie ustawowych obowiązków w tym zakresie odpowiadają przewodniczący zarządów związków. Na uwagę zasługuje również to, że podczas gdy niektóre związki nie wypełniały obowiązków ustawowych w zakresie dotyczącym kontroli zarządczej, inne poddały się badaniu audytowemu, mimo że nie ma ono charakteru obligatoryjnego w przypadku podmiotów, jakimi są związki (Informacja o wynikach kontroli..., 2012, s. 10).

Podczas działań kontrolnych uwaga NIK skierowana została na poprawność zapisów i treści znajdujących się w statutach związków. W tej sferze ocena dotyczyła przede wszystkim podziału kompetencji oraz kompleksowości regulacji zawartych w tych dokumentach. W jednym z badanych związków NIK wskazał na nadmierną koncentrację uprawnień i kompetencji przypisaną wiceprzewodniczącemu związku i określił możliwe, niepożądane konsekwencje w tym zakresie w postaci mechanizmu korupcjogennego. Kontrolerzy jako niewystarczający uznali także poziom szczegółowości postanowień statutu w zakresie zadań związku oraz zasad gospodarowania jego mieniem.

Istotną kwestią była również ocena poprawności wykonywania przez związki obowiązków, wynikających z ustawy prawo zamówień publicznych podczas realizacji projektów inwestycyjnych współfinansowanych ze środków publicznych. Naruszenia zasad w tym obszarze w opinii NIK wynikały podobnie, jak w przypadku wcześniej wskazanych nieprawidłowości, z nieskutecznego i niespełniającego wymagań systemu kontroli zarządczej. Uwagi NIK dotyczące stosowania przepisów prawa zamówień publicznych dotyczyły kwestii poprawności wyboru trybu udzielenia zamówienia, wypełniania obowiązków informacyjnych dotyczących publikacji ogłoszeń o zamówieniach, udokumentowania rozeznania cenowego w zamówieniach w kwocie poniżej 14 tys. euro (Informacja o wynikach kontroli..., 2012, s. 10).

Na etapie realizacji projektów główne zastrzeżenia NIK dotyczyły zaciągania zobowiązań finansowych bez wymaganego upoważnienia oraz nierzetelnego nadzoru nad przebiegiem zadań inwestycyjnych (m.in. kompletność i rzetelność wpisów w dzienniku budowy inwestycji, 
dla której inwestorem jest związek). Wiele uwag NIK dotyczyło także sposobu sporządzania wniosków o płatność (kwoty wydatków kwalifikowanych, numery ewidencyjne dokumentów itp.) oraz terminowości ich składania.

Ważnym obszarem poddanym ocenie NIK, obok poprawności realizacji projektów współfinansowanych ze środków publicznych, było gospodarowanie mieniem przez związki międzygminne. Kontrola dotyczyła zarówno nieruchomości zabudowanych i niezabudowanych, jak i takich form gospodarowania nimi jak sprzedaż, oddawanie w użytkowanie wieczyste, wnoszenie aportem, zamiana, darowizna (Informacja o wynikach kontroli..., 2011, s. 7).

Kontrolą w zakresie gospodarowania mieniem objęte zostały 32 związki, których działania poddano ocenie za okres od 1 stycznia 2003 roku do 30 czerwca 2009 roku. Przedmiot kontroli w przedmiocie zarządzania mieniem dotyczył w szczególności oceny prawidłowości gospodarowania mieniem przez związki, stanu prawnego nieruchomości, inwentaryzacji mienia i jego gospodarowaniem.

Z ustaleń uzyskanych na podstawie kontroli NIK wynika, że na dzień 30 czerwca 2009 roku 32 kontrolowane związki dysponowały nieruchomościami gruntowymi o łącznej powierzchni 117,8491 ha obejmującymi łącznie 133 działki geodezyjne (Informacja o wynikach kontroli gospodarowania mieniem przez związki międzygminne, 2011, s. 24). Stan prawny nieruchomości w dominującym stopniu był uregulowany. Mienie związków w latach 2003-2009 w dominującym stopniu ewidencjonowane było bez wykorzystania specjalistycznych narzędzi/technik oprogramowania i podlegało tradycyjnej, ręcznej formie zapisu. Za ewidencjonowanie mienia odpowiadali odpowiednio albo skarbnicy związku, albo też pracownicy specjalnie oddelegowani do realizacji tego zadania.

W zakresie inwentaryzacji mienia będącego w dyspozycji związków międzygminnych główne zastrzeżenia NIK dotyczyły kwestii niedokonania inwentaryzacji określonej grupy środków trwałych, niewłaściwym zrealizowaniu inwentaryzacji (tj. nierzetelności i nieprawidłowości), niepoprawnym udokumentowaniu wyników inwentaryzacji, nieterminowym zakończeniu inwentaryzacji.

W latach 2003-2009 związki międzygminne sporządzały informację o stanie mienia. Ten zakres aktywności związków poddany został ocenie NIK, na podstawie której ustalono, że w przeważającym stopniu wszystkie związki objęte kontrolą dysponowały informacją o stanie mienia, sporządzaną dla każdego z okresów objętych kontrolą, a jedynie nieliczne związki sporządzały takie informacje rzadziej niż raz w roku. Informacja o stanie mienia wraz z projektem uchwały budżetowej związku była przedstawiana w celu zaopiniowania RIO. Jak wynika z ustaleń kontroli, związki jedynie w nielicznych przypadkach nie dochowywały ustawowego terminu przedłożenia dokumentów do opinii, a opóźnienia względem wyznaczonego przepisami terminu wynosiły od 1 do 58 dni. We wszystkich badanych przypadkach RIO wydała pozytywne opinie względem treści przedłożonych jej przez związki dokumentów.

Istotnym zaniedbaniem w zakresie wypełnienia przez związki obowiązku informacyjnego było nieopublikowanie w BIP informacji o stanie mienia, mimo istnienia takiego wymogu (Informacja o wynikach kontroli gospodarowania mieniem przez związki międzygminne, 2011, s. 7).

Odpowiedzialność za gospodarowanie mieniem ponoszą zarządy związków, jako ich organy wykonawcze. Tę sferę objęto również kontrolą NIK. Sposób przypisania odpowiedzialność za gospodarkę mieniem w praktyce realizowany był przez kontrolowane związki w dwojaki sposób 
- albo przez wskazanie konkretnej osoby, albo nałożenia odpowiedzialności na wszystkich członków zarządu. Jednolity był natomiast sposób gospodarowania mieniem związków, które realizowały swoje obowiązki samodzielnie nie korzystając w tym zakresie z usług podmiotów zewnętrznych (zarządcy nieruchomości, rzeczoznawcy, pośrednicy w obrocie nieruchomościami). W przeważającej liczbie związków dostępna była kompleksowa informacja o posiadanym przez te podmioty mieniu i jego składnikach, które w większości przypadków były przez związki wykorzystywane i jedynie w nielicznych przypadkach mienie związków nie zostało udostępnione z uwagi na brak przydatności gospodarczej jego składników.

Ze względu na wykorzystanie przez związki składników mienia w praktyce rzadko zdarzały się przypadki sprzedaży przede wszystkim nieruchomości, jako głównej składowej mienia związków. Jeżeli dochodziło do obrotu nieruchomościami związków, to NIK nie odnotował nieprawidłowości w tym zakresie. Obok sprzedaży istotną formą zagospodarowania mienia związków było nieodpłatne przekazanie nieruchomości, bądź przekazanie mienia w najem lub dzierżawę. Wyniki kontroli NIK wskazują także na niestandardowe przypadki wykorzystania mienia przez związki, do czego dochodziło w przypadku utworzenia przez związek spółki lub zaangażowanie związku w tworzenie i działanie funduszu poręczeń kredytowych (Informacja o wynikach kontroli gospodarowania mieniem przez związki międzygminne, 2011, s. 33). W latach 2003-2009 związki dokonywały aktywnie zakupów nowych składników majątkowych lub zawierały umowy na ich dzierżawę lub wynajem od innych podmiotów.

Ogólne wnioski pokontrolne NIK nie wykazały rażących uchybień w gospodarowaniu mieniem przez związki międzygminne w okresie poddanym badaniu, nie stwierdzono tym samym znaczących uchybień wpływających na marnotrawienie środków publicznych przez te podmioty oraz nie wykryto działań rażącej niegospodarności w sferze zarządzania mieniem.

\section{Podsumowanie}

Polskie prawo przewiduje łączenie gmin w związki międzygminne, z czego korzysta, według stanu z grudnia 2016 roku, ponad 300 gmin. Pozytywnym aspektem tej formy organizacyjno-prawnej jest niewątpliwie współpraca na rzecz spełniania misji publicznej służącej zaspokajaniu potrzeb społeczności lokalnej. Mimo że ogólne wnioski pokontrolne NIK nie wykazały rażących uchybień, te na które wskazano były liczne. Do najbardziej negatywnych można zaliczyć braki związane z poprawnością dokonywania wydatków oraz sporządzania sprawozdań budżetowych i finansowych przez zarządy związków, terminowości dokonywania opłat (składek) członkowskich przez gminy będące uczestnikami związków, zgodności ze statutem związku działalności prowadzonej przez związek, uprawnień do reprezentowania gmin w zgromadzeniach związków przez wszystkich uczestniczących w nich przedstawicieli gmin, a w szczególności przez osoby uczestniczące zamiast wójtów, poprawności określania zadań publicznych związków w ich statutach (Informacja o wynikach kontroli gospodarowania mieniem przez związki międzygminne, 2011, s. 17). Wyeliminowanie takich uchybień jest warunkiem koniecznym do lepszego wykorzystania środków publicznych, szczególnie środków unijnych z perspektywy 2014-2020. Obecne wydarzenia w Europie (Brexit) nie pozwalają na jednoznaczne zapewnienie znaczących funduszy unijnych w przyszłych okresach programowania, dlatego zwiększenie efektywności 
wykorzystywania środków, kontrola wydatków i obsługa zadłużenia powinny stanowić jeden z priorytetów strategicznych związków międzygminnych.

\section{Literatura}

Salachna, J.M. (red.) (2010). Budżet $i$ wieloletnia prognoza finansowa jednostek samorzadu terytorialnego od projektu do sprawozdania. Gdańsk: ODDK.

Kosikowski, C., Salachna, J.M. (red.) (2012). Finanse samorzadowe. 580 pytań i odpowiedzi. Wzory uchwat, deklaracji, decyzji, umów. Warszawa: Wolters Kluwer business.

Informacja o wynikach kontroli. Funkcjonowanie wybranych związów międzygminnych w zakresie realizacji projektów wspólfinansowanych ze środków publicznych. Raport Najwyższej Izby Kontroli, LSZ-4101-29/2011 Nr ewid. 167/2012/P11167/LSZ, www.nik.gov.pl (10.11.2016).

Informacja o wynikach kontroli gospodarowania mieniem przez związi międzygminne. Najwyższa Izba Kontroli, Delegatura w Bydgoszczy, LBY 410-21-/2009 Nr ewid. 158/2010/P/09/127/LBY, Bydgoszcz, styczeń 2011 r., www. nik.gov.pl, 10.11.2016 r.

Interpretacja Dyrektora Izby Skarbowej w Katowicach. Pobrano z: http://interpretacja-podatkowa.pl/interpretacja/ pokaz/1-_podatek-od-towarow-i-uslug-oraz-podatek-akcyzowy_/2-podatek-od-towarow-i-uslug/118-podstawaopodatkowania/162604-dzialalnosc-statutowa-odplatnosc-opodatkowanie-skladka-czlonkowska-skladki-statutudzial.html (10.11.2016).

Kiełbus, M. (2012). Zadania związków międzygminnych, Gospodarka odpadami przez związki komunalne. Wspólnota, 41-42.

Kosek-Wojnar, M., Surówka, K. (2007). Podstawy finansów samorządu terytorialnego. Warszawa: Wydawnictwo Naukowe PWN.

Krajewski, S., Mackiewicz, M., Krajewski, P. (2010). Przygotowanie wieloletniej prognozy finansowej - wybrane problemy metodologiczne. Finanse Komunalne, 7-8.

Krawczyk, M. (2011). Związki i porozumienia międzygminne. Zeszyty Uniwersytetu Przyrodniczego w Siedlcach, Seria Administracja i Zarzadzanie, 91.

Ofiarska, M. (2012). Organizacja i finansowanie wspólnych przedsięwzięć związków międzykomunalnych. W: C. Kosikowski, J.M. Salachna (red.), Finanse samorządowe. 580 pytań i odpowiedzi. Wzory uchwat, deklaracji, decyzji, umów. Warszawa: Wolters Kluwer business.

Rozporządzenie Ministra Finansów z 5.07.2010 r. w sprawie szczególnych zasad rachunkowości oraz planów kont dla budżetu państwa, budżetów jednostek samorządu terytorialnego, jednostek budżetowych, samorządowych zakładów budżetowych, państwowych funduszy celowych oraz państwowych jednostek budżetowych mających siedzibę poza granicami Rzeczypospolitej Polski (Dz.U. 2010, nr 128, poz. 861 z późn. zm.).

Rozporządzenie Ministra Finansów z 2.03.2010 r. w sprawie szczegółowej klasyfikacji dochodów, wydatków, przychodów i rozchodów oraz środków pochodzących ze źródeł zagranicznych (Dz.U. 2010, nr 38, poz. 207 z późn. zm.).

Ustawa z 8.03.1990 r. o samorządzie gminnym (Dz.U. 2016 poz. 446).

Ustawa z 29.09.1994 r. o rachunkowości (Dz.U. 2016, poz. 1047).

Ustawa z 20.12.1996 r. o gospodarce komunalnej (Dz.U. 2016 poz. 573).

Ustawa z 13.11.2003 r. o dochodach jednostek samorządu terytorialnego (Dz.U. 2016, poz. 198).

Ustawa z 30.06.2005 r. o finansach publicznych (Dz.U. 2005, nr 249, poz. 2104 z późn. zm.).

Ustawa z 27 .08.2009 r. o finansach publicznych (Dz.U. 2009, poz. 1240, nr 157 z późn. zm.).

Stahl, M., Jaworska-Dębska, B. (2010). Encyklopedia samorządu terytorialnego dla każdego. Warszawa: Difin.

\section{Cytowanie}

Zioło, M., Oliwa, B. (2016). Organizacja i funkcjonowanie związków międzygminnych w Polsce. Współczesne Finanse. Teoria i Praktyka, 1 (1), 123-134. DOI: 10.18276/wf.2016.1-12. 